\title{
RER AND PROTAMINE-TYPE PROTEINS DURING CHARA TOMENTOSA L. SPERMIOGENESIS
}

\author{
MARIA KWIATKOWSKA, KATARZYNA POPŁOŃSKA \\ Department of Cytophysiology, University of Lodz \\ Pilarskiego 14, 90-231 Lodz, Poland \\ e-mail: Kwiat@biol.uni.lodz.pl
}

(Recived: March 11, 2002. Accepted: January 15, 2003)

\begin{abstract}
In Chara tomentosa during mid spermiogenesis (phases V, VI, VII) when the amount of nuclear protamine-type proteins increases, while the amount of histones decreases, in connection with chromatin remodelling, an extensive RER system filled with dark, fine-granular substance is observed. The intermembranous space of the nuclear envelope is filled with a homogenous substance which looks similar. The most extensive ER system can be observed in phase $\mathrm{V}$, which is at the beginning of nuclear protein exchange.

The results presented in this paper correspond with the earlier suggestion based on Chara vulgaris spermiogenesis studies, that ER takes part in a protamine-type protein synthesis, which enter a nucleus by endocytosis, through an inner nuclear envelope membrane.
\end{abstract}

KEY WORDS: Chara tomentosa L., Endoplasmic reticulum, EM observations, protamine-type proteins.

\section{INTRODUCTION}

During spermiogenesis in animals, a dramatic remodelling of chromatin takes place, leading to extreme condensation connected with the replacement of histones with protamines or other more basic proteins (Wouters-Tyrou et al. 1998; Steger 1999). In some plants producing swimming male gametes such as Marchantia polymorpha (Reynolds and Wolfe 1978), Equisetum arvense (Hadj-Mabrouk et al. 1979), Scolopendrium vulgare (Robert 1984) a similar phenomenon was described.

Capillar electrophoresis of mature spermatozoids of $C$. tomentosa has shown no histone proteins which are replaced with 3 fractions of basic proteins with electrophoretic mobility, similar to that of salmon protamines (Kaźmierczak 2000; Kwiatkowska et al. 2002). The studies have shown that a small amount of protamine-type protein appears in mid spermiogenesis, and reaches nearly a maximal level in late spermiogenesis. At that time core histones are still present while the amount of linker histones decreases.

As a result of cytochemical procedures according to Alfert and Geschwind (1953) as well as Bloch et al. (1961) methods, a precise moment when of protamines appeared and histones disappeared was established, due to the description of 10 phases of spermiogenesis on the basis of shape, size, structure and localisation of nucleus in a spermatid, as well as the degree of cytoplasm reduction. It was observed that positive reaction to protamine-type proteins appeared in phase $\mathrm{V}$, and then gradually increased (phases
VI-VIII) while the staining as a result of histone reaction diminished gradually and finally disappeared in phases IX and $\mathrm{X}$. At that time, the nucleus forms an elongated spiral baguette (Popłońska 2002).

Ultrastructural studies of $C$. vulgaris have shown that during spermiogenesis (which is divided into 10 phases, similar to $C$. tomentosa) an extensive ER system filled with fine-granular substance was observed in phase $\mathrm{V}$. The intermembranous space of the nuclear envelope was filled with a similarly looking homogenous substance (Kwiatkowska 1996; Kwiatkowska and Popłońska 2002). Simultaneously an intensive incorporation of ${ }^{3} \mathrm{H}$-arginine and ${ }^{3} \mathrm{H}$-lysine was observed which was seen over a nucleus in autoradiograms of semi-thin sections, already after 4-min incubation (Kwiatkowska and Popłońska 2002). On the basis of the above facts, a suggestion has been put forward that ER is the site of a synthesis of proteins taking part in a chromatin remodelling, towards an extremely condensed state characteristic of mature spermatozoids (Kwiatkowska 1996; Kwiatkowska and Popłońska 2002).

The aim of the present study was to verify whether there existed a correlation between an appearance of protaminetype proteins and a transient extensive ER during spermiogenesis of $C$. tomentosa - the species in which electrophoretic and cytochemical studies of basic proteins were carried out. It seems more important for our knowledge, that there is no information concerning the site of synthesis of protamines in a cell, and the way of their translocation from cytoplasm to a nucleus. Little is also known about ER 
during spermiogenesis. It is significant that in spite of detailed ultrastructural studies of spermiogenesis in several Chara species (C. fibrosa, Picket-Heaps 1968; C. contraria, Coccuci and Caceres 1976; C. vulgaris, Robert 1979) as well as Nitella missouriensis (Turner 1968), only in our papers concerning $C$. vulgaris the phase when ER is abundant was described (Kwiatkowska 1996; Kwiatkowska and Popłońska 2002).

The present study has shown that this characteristic period (when extensive ER fills with a dark, fine-granular substance preceding deep structural changes of the spermatid nucleus) also occurs in $C$. tomentosa.

\section{MATERIAL AND METHODS}

Apical parts of thallus of Chara tomentosa were obtained from plants taken from the lake, situated close to the village of Powidz, near Konin (Poland).

Antheridia were taken from III-V node pleuridia, counting from the apex. Before the start of the experiment, the plants were cultivated for a few days in tanks containing water from the natural environment, at a photoperiod $\mathrm{L}: \mathrm{D}=14: 10$.

Selected C. tomentosa plants were fixed in Sörensen phosphate-buffer $(0.125 \mathrm{M}, \mathrm{pH} 7.2)-3 \%$ glutaraldehyde for $3 \mathrm{~h}$ at $4{ }^{\circ} \mathrm{C}$, and supplemented with $0.007 \mathrm{M} \mathrm{CaCl}_{2}$. Antheridia were isolated and squashed in a drop of heated $2 \%$ agar in Sörensen phosphate-buffer, and postfixed in $1 \%$ $\mathrm{OsO}_{4}$ in $0.125 \mathrm{M}$ of veronal buffer, for $1 \mathrm{~h}$. After dehydration in alcohol series, the material was embedded in Spurr's medium. Ultrathin sections were double stained with uranyl acetate and lead citrate, according to Reynolds. The sections were examined and photographed in a JEOL JEM -1010 TEM.

\section{RESULTS AND DISCUSSION}

Studies of consecutive 10 phases of $C$. tomentosa spermiogenesis show that ER is non-extensive during the first period (phases I-II). The amount of ER and vesicles increases during next phases (III-IV), when cell polarisation is more evident. However, also in these phases ER, as well as intermembranous space of the nuclear envelope, are filled with electron-transparent substance (Fig. 1). Variously formed ER with dark contents appears in C. tomentosa, as in C. vulgaris, only in phase V (Fig. 2) when a nucleus is situated close to plasmalemma (Kwiatkowska 1996; Kwiatkowska and Popłońska 2002). During this phase, dense chromatin is mostly adjacent to the nuclear envelope, and forms a thick ring. ER are variously positioned in the cell: peripherally near plasmalemma, as well as often very close to the nucleus, mostly arranged parallel to its surface. They are connected by short bridges and are continuous with the nuclear envelope. The nuclear envelope with few pores contains a dark substance in its intermembranous space, which looks like that inside ER.

During the transitory period between phases V and VI, ER is still abundant (Fig. 3). ER is often swollen, and the space between it is filled with numerous free ribosomes. Condensation of cytoplasmic structures results from a significant decrease in the volume of cytoplasm.
Phase VI, when dense chromatin forms a network, is still characterised by ER, with substantially reduced cytoplasm (Figs 4, 5). However, often RER forms vesicles, which are filled with a dark substance, like cisternae. Also electrontransparent vesicles are numerous; they can be ER vesicles without their contents, or Golgi vesicles, because similar vesicles are abundant around dictyosomes.

During phase VII, when randomly positioned fibrils appear in a nucleus, ER cisternae are shorter and wider than before and numerous ER vesicles are found. Both of them contain a grey substance, and electron-transparent vesicles are also numerous (Fig. 6).

During phase VIII, when chromatin is fibrillar, only few ER vesicles are observed in substantially reduced cytoplasm (Fig. 7). However, they are not visible in phase IX, when nuclear chromatin is lamellar, and in phase $\mathrm{X}$ when chromatin is extremely condensed, and a spermatozoid is nearly fully formed (Kwiatkowska et al. 2002).

The presented pictures together with biochemical and cytochemical results show that ER filled with a dark, finegranular substance appears in the phases, during which the amount of protamine-type proteins increases, i.e. in phases V, VI, VII preceding the formation of a nucleus with fibrillar chromatin. ER is most abundant in phase $\mathrm{V}$, when replacement of nuclear proteins begins.

Coexistence of both phenomena suggests that ER may take part in protamine-type protein synthesis, which is involved in chromatin remodelling. These substances may be translocated from ER to the nucleus via an intermembranous space of the nuclear envelope, by endocytosis. Invaginations of the nuclear envelope's inner membrane into nucleoplasm observed in $C$. vulgaris (Kwiatkowska and Popłońska 2002) may indicate such a possibility. In C. tomentosa, similar pictures are also observed, but less often. This process, however, can be very dynamic and difficult to catch in EM pictures.

Nuclear transport by endocytosis was described by Singh et al. (1998) in placenta cells in Lilium. They showed continuity between ER, nuclear envelope and lumen, so-called nuclear reticulum, using ZJO technique of impregnation of endomembrane systems, which seemed to be involved in the translocation of a nucleus.

To our knowledge, in literature concerning ER function as well as spermiogenesis in plants and animals, there are no data supporting our suggestion concerning ER connection with protamine-type protein synthesis. Many authors demonstrate that ER plays a very important role, and is involved in various cellular processes. It takes part in synthesis, accumulation and prolonged retention of proteins, and also contains a system which makes structural modification and quantitative control of proteins possible. Additionally, it takes part in triggering of the process of proteins leaving $\mathrm{ER}$, and moving to their destination in response to signals indicating it (Elgard et al. 1999; Pagny et al. 1999; Baumann and Walz 2001). Thus, it seems possible that ER could be a site of protamine-type protein synthesis. This hypothesis, however, requires more research.

\section{ACKNOWLEDGEMENTS}

This work was supported by the National Committee of Scientific Research, grant no 6 PO4C 05317. 

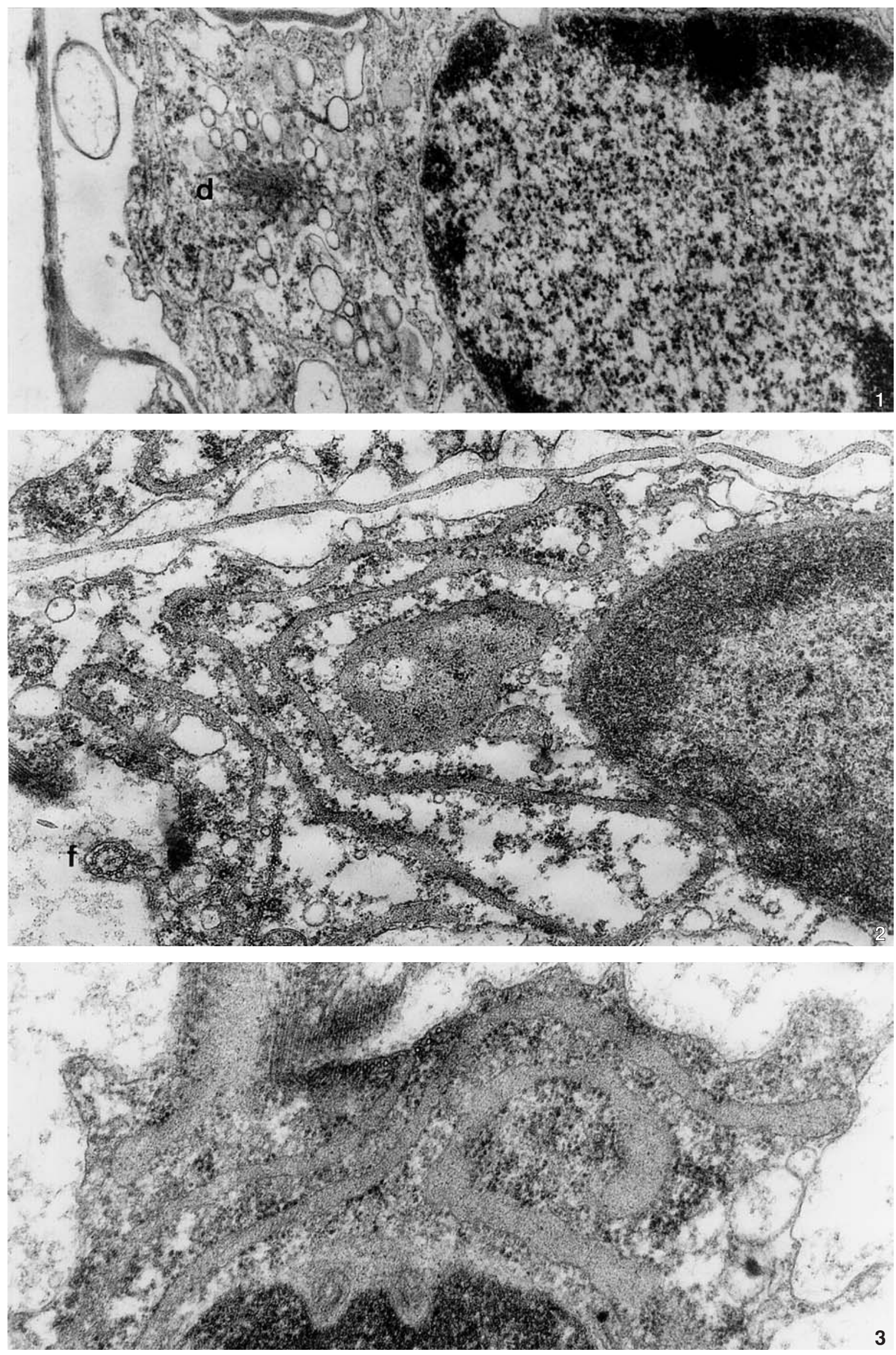

Fig. 1. C. tomentosa spermiogenesis - phase IV. ER with electron transparent content. Protoplast moved away from a cell wall, $\mathrm{d}-$ dictyosom, ca $\times 28000$. Fig. 2. Spermiogenesis - phase V. ER and intermembranous space of a nuclear envelope with dark fine-granular content. Dense chromatin forms a layer adjacent to a nuclear envelope, $\mathrm{f}-$ flagellum, ca $\times 32000$.

Fig. 3. Spermiogenesis - phase V/VI. Swollen ER cisternae filled with a fine-granular substance, ca $\times 56000$. 

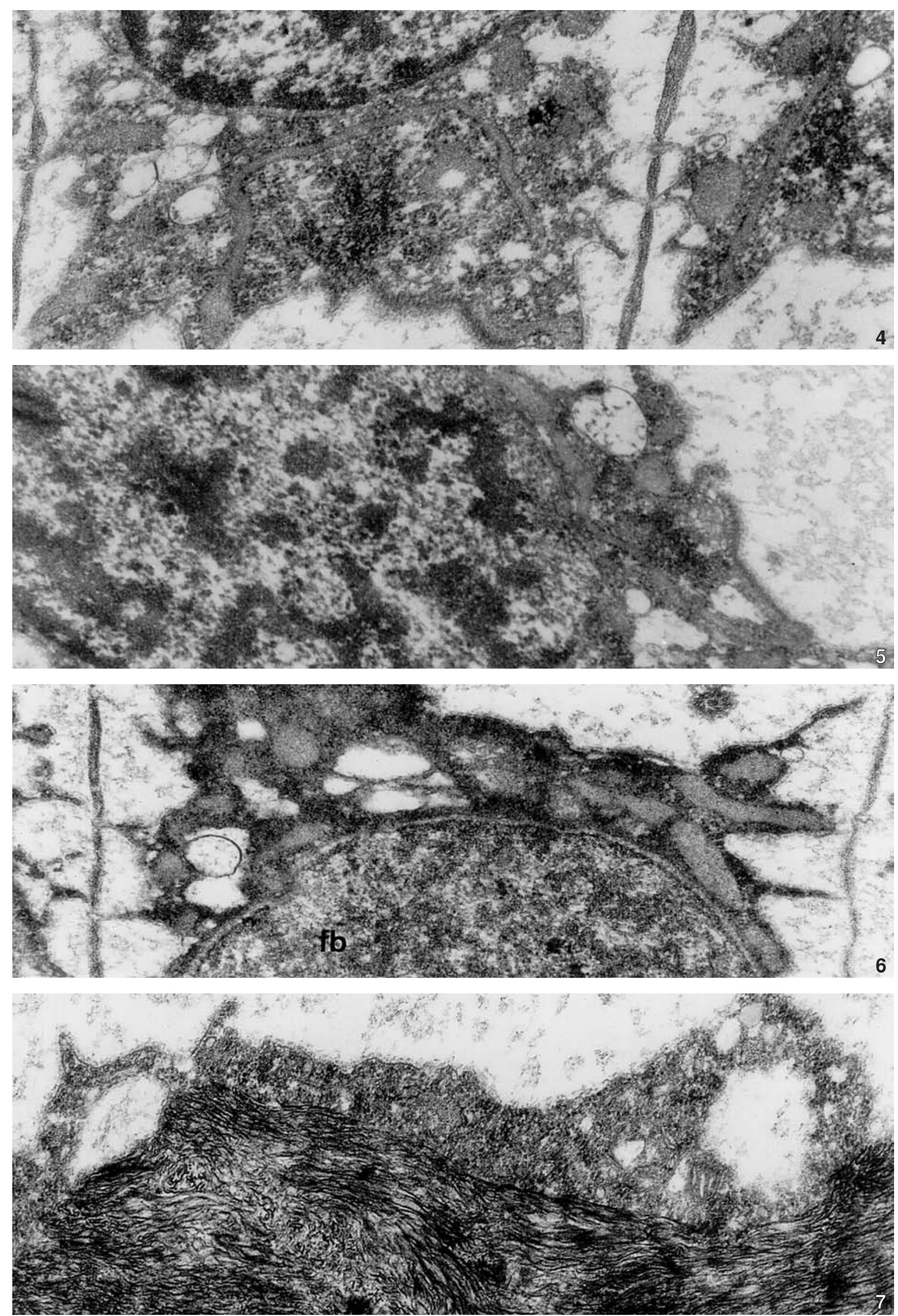

Figs 4, 5. Spermiogenesis - phase VI. ER cisternae and vesicles filled with a fine-granular substance. Nucleus with chromatin forming a network. Fig. 4 ca $\times 36000$, Fig. 5 ca $\times 30000$.

Fig. 6. Spermiogenesis - phase VII. ER cisternae and vesicles filled with a fine-granular substance. Short, randomly positioned fibrils (fb) visible in a nucleus, ca $\times 32000$.

Fig. 7. Spermiogenesis - phase VIII. Nucleus with fibrillar chromatin, ca $\times 50000$. 


\section{LITERATURE CITED}

ALFERT M., GESCHWIND I. 1953. A selective staining method for the basic proteins of cell nuclei. Proc. Nat. Acad. Sci. USA 39: 991-998.

BAUMANN O., WALTZ B. 2001: Endoplasmic reticulum of animal cells and its organization into structural and functional domains. Int. Rev. Cytol. 205: 149-214.

BLOCH D.P., HOWARD Y.C., HEW M.S. 1961. Methods for the cytochemical characterization of nuclear basic proteins and their application to problems of development. Ann. Histochim. 7: 497-500.

COCUCCI A.E., CACERES E.J. 1976. The ultrastructure of the male gametogenesis in Chara contraria var. Nitelloides (Charophyta). Phytomorphology 26: 5-16.

ELLGARD L., MOLINARI M., HELENIUS A. 1999. Setting the standards: quality control in the secretory pathway. Science 286: $1882-1888$

HADJ-MABROUK H., KADER J.C., ROBERT D. 1979. Les protéines basiques du noyau du spermatozoide de l'Equisetum arvense L. Etude par electrophorèse. C R Acad. Sc. Paris 289: 969-972.

KAŹMIERCZAK A. 2000. Electrophoretic analysis of qualitative and quantitative changes of basic proteins during spermiogenesis of Chara. Acta Biol. Cracov. Ser. Bot. 42, suppl. 1: 45.

KWIATKOWSKA M. 1996. Changes in ultrastructure of cytoplasm and nucleus during spermiogenesis in Chara vulgaris. Folia Histochem. Cytobiol. 34: 41-56.

KWIATKOWSKA M., KAŹMIERCZAK A., POPŁOŃSKA K. 2002. Ultrastructural, autoradiographic and electrophoretic examinations of Chara tomentosa spermiogenesis. Acta Soc. Bot. Pol. 71: 201-209.

KWIATKOWSKA M., POPŁOŃSKA K. 2002. Further ultrastructural research of Chara vulgaris spermiogenesis: endopla- smic reticulum, structure of chromatin, ${ }^{3} \mathrm{H}$-lysine and ${ }^{3} \mathrm{H}$-arginine incorporation. Folia Histochem. Cytobiol. 40: 85-97.

PAGNY S., LEROUGE P., FAYE L., GOMORD V. 1999. Signals and mechanisms for protein retention in the endoplasmic reticulum. J. Exp. Bot. 50: 157-164.

PICKETT-HEAPS J.D. 1968. Ultrastructure and differentiation in Chara (Fibrosa) IV Spermatogenesis. Aust. J. Biol. Sci. 21: 655-690.

POPŁOŃSKA K. 2002. Cytochemical studies on histone-type and protamine-type proteins during spermiogenesis in Chara vulgaris and Chara tomentosa. Folia Histochem. Cytobiol. 40: 233-234.

REYNOLDS W.F., WOLFE S.T. 1978. Changes in basic proteins during sperm maturation in a plant, Marchantia polymorpha. Exp. Cell Res. 116: 269-273.

ROBERT D. 1979. Localisation cytochimique en microscopie électronique, des constituans nucléaires au cours de la spermiogenése chez le Chara vulgaris. Ann. Sc. Nat. Bot. Paris 1: 67-80.

ROBERT D. 1984. Le noyau du gaméte mâle chez les végétaux. Plant sperm nucleus. Ann. Sc. Nat. Bot. Paris 6: 151-164.

SINGH S., LAZZARO M.D., WALLES B. 1998. The nuclear reticulum in placental cells of Lilium regale is a part of endomembrane system. Protoplasma 203: 144-152.

STEGER K. 1999. Transcriptional and translational regulation of gene expression in haploid spermatids. Anat. Embryol. 199: 471-487.

TURNER F.R. 1968. An ultrastructural study of plant spermatogenesis. Spermatogenesis in Nitella. J. Cell Biol. 37: 370-393.

WOUTERS-TYROU D., MARTINAGE A., CHEVAILLIER P., SAUTIÈRE P. 1998. Nuclear basic proteins in spermiogenesis. Biochimie 80: 117-128.

\section{RER A BIAŁKA TYPU PROTAMIN \\ W SPERMIOGENEZIE CHARA TOMENTOSA L.}

\section{STRESZCZENIE}

W środkowej spermiogenezie Chara tomentosa (faza V, VI, VII), gdy zwiększa się ilość jądrowych białek typu protamin, a jednocześnie zmniejsza się ilość histonów w związku z reorganizacją struktury chromatyny, obserwuje się silnie rozbudowany system RER wypełniony ciemną, drobnoziarnistą substancją. Tak samo wyglądająca substancja znajduje się w międzybłonowej przestrzeni otoczki jądrowej. Najbardziej obfity system ER obserwuje się $\mathrm{w}$ fazie $\mathrm{V}$, tj. na początku wymiany białek jądrowych. Wyniki przedstawione w obecnej pracy są zgodne z wcześniej wysuniętą sugestią opartą o badania spermiogenezy Chara vulgaris, iż ER bierze udział w syntezie białek typu protamin, które wnikają do jądra w drodze endocytozy poprzez wewnętrzną błonę otoczki jądrowej.

SŁOWA KLUCZOWE: Chara tomentosa L., retikulum endoplazmatyczne, obserwacje elektronowomikrokroskopowe, białka typu protamin. 